\title{
Systems in Context \\ On the outcome of the Habermas/Luhmann-debate
}

\author{
Poul Kjaer
}

\begin{abstract}
${ }^{1}$
Usually regarded as a 1970s phenomenon, this article demonstrates that the debate between Jürgen Habermas and Niklas Luhmann continued until Luhmann's death in 1998, and that the development of the two theorists' positions during the 1980s and 1990s was characterised by convergence rather than by divergence. In the realm of legal theory, the article suggests, convergence advanced to the extent that Habermas' discourse theory may be characterised as a normative superstructure to Luhmann's descriptive theory of society. It is further shown that the debate's result was an almost complete absorption of Habermas' theory by Luhmann's systems theoretical complex - an outcome facilitated by Luhmann's deliberate translation of central Habermasian concepts into systems theoretical concepts. The article argues that both the debate and Habermas' conversion were made possible because not only Habermas' but also Luhmann's work can be considered a further development of the German idealist tradition. What Luhmann did not acknowledge was that this manoeuvre permitted the achievement of Habermas' normative objectives; nor did he notice that it could eradicate a central flaw in the system theoretical construction, by allowing the context within which distinctions are drawn to be mapped - an issue of pivotal importance for grasping relationships between different social systems, and coordinating them, via the deployment of legal instruments.
\end{abstract}

\section{Introduction}

In the 1970s, much of German social theoretical discourse centred around the debate between Niklas Luhmann (1927-98) and Jürgen Habermas (1929-), that was launched in 1971 by their publication Theorie der Gesellschaft oder Socialtechnologie - was leistet die Systemforschung? ${ }^{2}$ The central question in this debate was whether the idea of emancipation through rational political steering - the core element in Enlightenment thinking, as well as in German idealism - could still be considered as meaningful. Luh-

1 European University Institute, Florence. E-Mail: poul.kjaer@iue.it. The author would like to thank Claire $\mathrm{O}^{\prime}$ Brian and Henning Trüper for extensive comments on an earlier draft. Responsability for content remains with the author.

2 Jürgen Habermas/Niklas Luhmann, Theorie der Gesellschaft oder Sozialtechnologie - was leistet die Systemforschung? (Frankfurt am Main. Suhrkamp Verlag, 1971). mann argued that it could not. Habermas conversely advocated for a revitalisation of Enlightenment ideals and German idealism, to be achieved by development of an ,updated' theory of emancipation. ${ }^{3}$

At a first glance, the debate ended with publication of Habermas' Theorie des kommunikativen Handelns (1981) and Luhmann's Soziale Systeme (1984). Subsequently, it was widely thought, the two theoreticians had moved so far away from each other that they no longer had anything to discuss. Luhmann's staging of Soziale Systeme as a work which paved the way for a social theoretical paradigm shift from thinking in identity to thinking in distinctions, ${ }^{4}$ was seen as confirming this view. ${ }^{5}$ According to Luhmann himself, the latter move represented systems theory's final break with Enlightenment thinking and the German idealist tradition and, therefore, with the starting point of Habermasian theory. ${ }^{6}$

It is the argument of this article, however, that it remains both possible and fruitful to articulate Habermas' theoretical ambitions, as they have developed since the publication of Theorie des kommunikativen Handelns, using system theoretical tools advanced by Luhmann from the publication of Soziale Systeme onwards.

Such an undertaking is less controversial than it may at first appear. Luhmann himself initiated such a project in the years after publication of Theorie des kommunikativen Handelns by posing the question: „Was wäre gewonnen, was ginge verloren, wollte man die Theorie der rational argumentierenden kommunikativen Praxis in eine Theorie autopoietischer Kommunikationssysteme übersetzen?"

3 The rather misleading term philosophy of consciousness is normally used to capture the tradition from Descartes to Husserl, whereas the term German idealism is used as a narrower concept which covers the theoretical development from Fichte to Husserl. However, in the lack of a better concept German idealism is in this text used in a broader sense, which captures the tradition from Kant, Fichte and Hegel over Husserl to Habermas.

4 Niklas Luhmann, Soziale Systeme. Grundriß einer allgemeinen Theorie (Frankfurt am Main. Suhrkamp Verlag, 1984), p. 18ff.

5 E.g. Urs Stäheli: Sinnzusammenbrüche. Eine dekonstruktive Lektüre von Niklas Luhmanns Systemtheorie (Weilerswist, Velbrück Wissenschaft, 2000), p. 14.

6 The term systems theory is throughout the article used synonymously with Luhmann's systems theory. 
Poul Kjaer - Systems in Context

He made his reply in a number of articles, often disregarded, in which he presented a system theoretical reformulation of central Habermasian concepts, such as lifeworld (Lebenswelt), ${ }^{8}$ understanding (Verstehen $)^{9}$ and trust (Vertrauen). ${ }^{10}$

Yet Luhmann never completed this task. In the late 1980s, his direction altered as he increasingly focussed on the concept of paradox, which he had drawn from the work of George Spencer Brown. ${ }^{11}$ Additionally, Luhmann's attempted translation of central Habermasian into systems theoretical concepts was a one-sided project. Consequently, he failed to appreciate that such an enterprise inevitably builds a Trojan horse, with potential profoundly to alter systems theory's self-understanding and world-perspective.

This article advances eight hypotheses: 1 . The central difference between Habermas' and Luhmann's theoretical positions is reducible to a difference in assessment of the time-consuming character of social operations. 2. Habermas' position is based on the concept of lifeworld; but this concept lacks logical coherence. 3 . The concept of reiteration, presented by Luhmann as an alternative to the concept of lifeworld, is logically more stringent. 4. Luhmann's the-

7 Niklas Luhmann, Autopoesis, Handlung und Kommunikative Verständigung (Zeitschrift für Soziologie, Jg. 11, Heft 4, Oktober 1982, pp. 366-379), p. 376.

8 Niklas Luhmann, Die Lebenswelt - nach Rücksprache mit Phänomenologen (Archiv für Rechts- und Sozialphilosophie, vol. 72, Heft. 2, pp. 176-94, 1986).

9 Niklas Luhmann, Systeme Verstehen Systeme, pp. 72-117 in: Niklas Luhmann and Karl Eberhard Schorr (Hrsg.), Zwischen Intransparenz und Verstehen. Fragen an die Pädagogik (Frankfurt am Main, Suhrkamp Verlag, 1986).

10 Niklas Luhmann, Familiarity, Confidence, Trust: Problems and Alternatives, pp. 94-107 in: Diego Gambetta (ed.), Trust: Making and Breaking Cooperative Relations (New York. Basil Blackwell Ltd, 1988). The concept of trust is, strictly speaking, not a habermasian concept. By Luhmann the concept of trust can, however, be understood as complementary to the concept of meaning, in the sense that it represents a specific form for the concretisation of meaning. The presence of trust furthermore acts as a precondition for achieving understanding. Consequently, the system theoretical path from meaning over trust to understanding seems to be very similar to the path from lifeworld over communicative action to understanding in Habermas' work.

11 This move towards a focus on paradox was more precisely launched with the publication of Luhmann's contribution to feminology in 1988: See Niklas Luhmann, Frauen, Männer und George Spencer Brown (Zeitschrift für Soziologie, Jg. 17, Heft 1; Februar, 1988, pp. 47-71). It will be illustrated later on that this move towards a focus on paradox did not solve the problems which it was supposed to solve, since it did not establish a link between the logical foundations of the systems theory and the level for concrete analysis' of social phenomena's, just as it did not provide the theory with an mechanism which can be used to clarify what it is a given system is constituting itself against. oretical elaboration nonetheless failed to grasp the importance of context for the constitution of social phenomena, sharply reducing its strength. 5 . This shortcoming can be traced to Luhmann's attempt to de-couple systems theory from the German idealist tradition - which he executed via a sophisticated self-mystification strategy, which sought to present systems theory as a new theory, lacking connection to any existing tradition of social thought. Foundational, in constructing this mythology, was the concept of paradox. 6 . Removing this self-mystifying overlay, the social theoretical toolbox assembled by Luhmann can be used to promote a radically different world-perspective, lacking the kind of scepticism dominating the late Luhmann's systems theory, and which accords with the German idealist tradition from which systems theory originally emerged. 7. Consequently, Luhmann's and Habermas' legal theories can be viewed as owning a common basis in the German idealist tradition, which provides a structural basis for their conversion. 8 . Such a conversion allows for an understanding of the two theories as complementary, in so far as the late Habermas' discourse theory becomes a normative superstructure to Luhmann's descriptive theory of the society.

\section{Time}

The difference between Luhmann and Habermas' theoretical constructions is a difference in time. The central importance of time in Luhmann's work manifests in his adoption of the mantra in George Spencer Brown's calculus of indication: "Draw a distinction". ${ }^{12}$ The purpose of introducing such a distinction is to produce a difference, because only a difference between this and that makes possible the observation of this or that. ${ }^{13}$ According to Luhmann, the drawing of a distinction is an operation that unfolds in time. It takes time for someone - that is, the observer, who is always presupposed ${ }^{14}$ - to draw or set a border, thereby constituting a form: „Formsetzung ist ...Unterscheiden, und

12 George Spencer-Brown, Laws of Form (London. George Allen and Unwin Ltd, 1969), p.3. Importantly, distinctions are always made within a given context in Spencer-Brown's account.

13 Niklas Luhmann, Das Erkenntnisprogramm des Konstruktivismus und die unbekannt bleibende Realität, pp. 31-58 in: Niklas Luhmann, Soziologische Aufklärung 5. Konstruktivistische Perspektiven (Opladen, Westdeutscher Verlag, 1990), p. 34.

14 According to both Luhmann and Spencer-Brown, the assumption of an observer does not imply an ontological point of departure: the assumption is "brought back" into the calculus through a socalled re-entry operation. A re-entry operation implies that the form re-emerges in itself and, thereby, constitutes itself as a selfreferential phenomenon. Furthermore, self-referentiality implies that the first distinction is the distinction between the observer and the observed, and that it is this distinction which is brought back, with the consequence that it becomes possible for the observed to observe itself. 
Poul Kjaer - Systems in Context

Unterscheiden ist eine Operation. Und das setzt, wie alles Operieren, Zeit voraus“. ${ }^{15}$

But introducing a distinction is only the first step. An observer also needs to indicate one side of the distinction in order to remain attached to the distinction. So, Luhmann defines observation as the unity of distinction and indication: „Observing means making a distinction and indicating one side (and not the other side) of the distinction“ ${ }^{16}$ But both sides cannot be simultaneously indicated - even though they are constituted in the same moment - since that will lead to the distinction's disappearance. On the basis of difference between distinction and indication, therefore, Luhmann concludes that distinction-making operations are characterised by structural simultaneousness and operative non-simultaneousness: „Struktural gesehen existiert die Zwei-Seiten Form im Zeitmodus der Gleichzeitigkeit. Operativ gesehen ist sie nur im Nacheinander der Operationen aktualisierbar “ ${ }^{17}$

This difference between structural simultaneousness and operative non-simultaneousness is central to Luhmann's attempt to theorise the relationship between systems and their surroundings. But beyond this, it is the central element in the theory of autopoesis which Luhmann presented in Soziale Systeme, and which he later coupled to his version of the calculus of indication. ${ }^{18}$ The theory of autopoesis is used by Luhmann to conceptualise the reproduction of distinction making. Autopoetic systems are defined as systems which produce the conditions of their own existence. Operations are their constitutive element, in the sense that autopoietic systems maintain themselves through operations recursively attached to preceding operations. ${ }^{19}$ Consequently, a system only exists as an actually ongoing operation for the time period between the preceding and the following operation. ${ }^{20}$ As a result, autopoetic systems are characterised by an autonomous consciousness of time, in the sense that no direct equivalence exists between a system's internal time consciousness and time consciousness

15 Niklas Luhmann, Die Paradoxie der Form, pp. 197-212 in: Dirk Baecker (Hrsg.), Kalkül der Form (Frankfurt am Main. Suhrkamp Verlag, 1993), p. 199. Exactly when a calculus starts generating time, however, is disputed. Luhmann claims that all difference-making operations imply the existence of time: Niklas Luhmann, „Die Paradoxie der Form", p. 198f. With reference to Spencer-Brown, Dirk Baecker, however, claims that: „Die Unterscheidungsoperation verbraucht keine Zeit... Zeit kommt ...erst auf der Ebene der Unterscheidung von Unterscheidungen ins Spiel", that is when self-referentiality has already been established. See Dirk Baecker, Im Tunnel. pp.12-37, in: Dirk Baecker (Hrsg.) Kalkül der Form (Frankfurt am Main, Suhrkamp Verlag, 1993) p. 29.

16 Niklas Luhmann, The Paradox of Observing Systems (Cultural Critique. Fall, pp. 37-55, 1995), p. 43.

17 Niklas Luhmann, „Die Paradoxie der Form“, p. 202. in its surroundings. Every change within a system takes place according to the system's own tempo and in the system's own rhythm. Consequently, it can be concluded, it is not only according to the calculus of indication, but also according to the theory of autopoesis, that social systems should be understood as phenomena operating in their own time.

That systems operate in their own time has far reaching consequences: „Was gleichzeitig ist läßt sich nicht beeinflussen, läßt sich nicht in die Kausalkonstellationen des Systems einbeziehen, läßt sich nicht synchronisieren “. ${ }^{21}$ In other words, any attempt to understand relations between systems as causal relations are doomed to fail: „denn Kausaliät erfordert eine Zeitdifferenz zwischen Ursachen und Wirkungen, also ein Überschreiten der Zeitgrenzen des Gleichzeitig-Aktuellen“. ${ }^{22}$

18 This autopoetical concept is not an Luhmanian invention. Rather, it should be considered as a modernised version of Husserl's Phänemenologie des inneren Zeitbewußtseins. See Edmund Husserl, Vorlesungen zur Phänemenologie des inneren Zeitbewußtseins, in: R. Boehm (Hrsg.), Husserliana X (Den Haag, 1966). This has been pointed out by Armin Nassehi among others. See Das Identische "ist" das Nicht-identische. Bemerkungen zu einer theoretischen Diskussion um Identität und Differenz (Zeitschrift für Soziologie, Jg. 22, Heft 6, Dezember, 1993, pp. 477-81). Both Luhmann and Husserl seem attached to Fichte's concept of the subject which constitutes itself. See Johann Gottlieb Fichte, Über den Begriff der Wissenschaftslehre oder der sogenannten Philosophie (Stuttgart. Philipp Reclam Jun., [1794], 1972), Niklas Luhmann, "Soziale Systeme“, p. 60, Armin Nassehi, "Das Identische ,ist' das Nicht-identische“ and Marek J. Siemek, Fichtes und Husserls Konzept der Transzendentalphilosophie, pp. 96-116, in: Wolfram Hogrebe (Hrsg.): Fichtes Wissenschaftslehre 1794. Philosophische Resonanzen, (Frankfurt am Main. Suhrkamp Verlag, 1995). Additionally, Husserl's concept is closely affiliated to Augustine's theory of time, which Luhmann also seems to be aware of: See Niklas Luhmann, Die neuzeitlichen Wissenschaften und die Phänomenologie, (Wien, Picus Verlag, 1995), p. 35, footnote 23. Thence, it is possible to retrace the genealogy to Aristotle's theory of temporal substantiality. See Montgomery Forth, Transtemporal Stability in Aristotelian Substances (The Journal of Philosophy, vol. 75, 1978), pp. 624-646.

19 In Humberto Maturana's words: autopoetic systems „....are systems that are defined as unities as networks of productions of components that recursively, through their interactions, generate and realise the network that produces them and constitute, in the space in which they exist, the boundaries of the network as components that participate in the realisation of the network". See Humberto R. Maturana, Autopoesis, in Milan Zeleny (ed.): Autopoesis: A theory of living Organization (New York, North Holland, 1981), p. 21. Also quoted in Niklas Luhmann, Essays on Self-reference (New York/Oxford, Columbia University Press, 1990), p. 3.

20 Or, in Jean Clam's expression, a system is „,...a ,non-real', purely ,actual' system, containing nothing and made of nothing but operations". See Jean Clam, System's Sole Constituent, the Operation: Clarifying a Central Concept of Luhmannian Theory (Acta sociologica, Vol. 43, Nr. 1, 2000, pp. 63-79), p. 63.

21 Niklas Luhmann, "Das Erkenntnisprogramm des Konstruktivismus und die unbekannt bleibende Realität", p. 42. 
Poul Kjaer - Systems in Context

The conceptualisation of social phenomena as noncausal runs through Luhmann's work as a major theme from beginning to end. Causality was the principal topic of his first publication, Der Funktionsbegriff in der Verwaltungswissenschaft ${ }^{23}$ (1958), and predominant in his first large theoretical work, Zweckbegriff und Systemrationalität (1968). In the latter, influenced by the works of Ernst Cassirer, he adopted Kant's concept of „,causality of freedom“: „Das Kausalschema ist kein Schema der Determination, sondern ein Schema der Freiheit", 24 in so far as, "Ursachen und Wirkungen, also Input und Output, wechselseitig füreinander als Gesichtspunkte der Selektion fungieren “: ${ }^{25}$ Thus, the rejection of the notion of causality cannot be understood as a consequence of the introduction of the calculus of indication or the concept of autopoesis. Instead, the introduction of these new tools delivers a final argument for a longstanding desire to reject the notion of causality.

Thus, introduction of the theory of autopoesis and the calculus of indication undoubtedly increase the possibilities for observation: they are more potent, and more sophisticated, than the tools of observation developed in Luhmann's' earlier work. Yet, they do not necessarily enable our perception of the world in a completely different light, as Luhmann in effect claims, by staging Soziale Systeme as the pile driver in a radical social theoretical paradigm shift, which implies a change from thinking in identity to thinking in difference. Or, differently expressed: the introduction of these new tools sharpens system theoretical ideas, but does not entail any fundamental alteration to the social perspective of systems theory, since the point of departure for ,thinking the social' in Luhmann's work, both before and after Soziale Systeme, remains the idea that society can be understood as a "causality-free zone".The drastic theoretical consequences Luhmann derives from the distinction-theoretical turn thus appear arbitrary. Immanent reason appears lacking for the shift in perspective between the early Luhmann, who in 1968 chose to focus on freedom of selection, due to the non-existence of causality, and the „in-

22 Niklas Luhmann, Die Gesellschaft der Gesellschaft (Frankfurt am Main, Suhrkamp Verlag, 1997), p. 605.

23 Niklas Luhmann, Die Funktionsbegriff in der Verwaltungswissenschaft, (Verwaltungsarchiv. Zeitschrift für Verwaltungslehre, Verwaltungsrecht und Verwaltungspolitik, vol. 49, 1958, pp. 97-105).

24 Niklas Luhmann, Zweckbegriff und Systemrationalität. Über die Funktion von Zwecken in Sozialen Systemen (Frankfurt am Main, Suhrkamp Verlag, 1968), p. 250.

25 Ibid. p. 250. Luhmann's italics. See also Gorm Harste, Kant und Luhmann über Teleologie in politischer Kommunikation und Natur, pp. 169-83 in Gorm Harste, Thomas Mertens and Thomas Scheffer (Hrsg.), Immanuel Kant über Natur und Gesellschaft (Odense, Odense University Press, 1996). creasingly anarchical“ later Luhmann, who instead chose to observe the other side of the medal, stating: „Gleichzeitigkeit ist Chaos". ${ }^{26}$

In contrast to Luhmann's emphasis on structural simultaneousness and operative non-simultaneousness of social operations, Habermas argues that social operations are characterised by structural and operative simultaneousness. Habermas' approach derives from the notion of inter-subjectivity, which claims "sprach- und handlungsfähigen Subjekten ${ }^{\prime 27}$ are constituted through their relations to other subjects. Consequently, the existence of a plurality of subjects must be regarded as a structural condition. This point of departure Habermas combines with the possibility of an operationally-established concordance between two or more subjects' view on the world. More precisely, it is „die Gleichursprünglichkeit von Darstellung, Kommunikation und Handeln ${ }^{\prime 28}$ which creates this possibility for objectivity, since „einer Verständigt sich mit einem anderen über etwas in der Welt" ${ }^{29}$ Habermas argues, in other words, that communicative acts can be understood as operations which, without generating time, can establish accordance between two or more subjects' perspective on the world: „Als Darstellung und als kommunikativer Akt weist die sprachliche Äußerung in beide Richtungen zugleich. Zur Welt und zum Adressaten“. ${ }^{30}$

\section{Lifeworld}

It is to illustrate the centrality of operative simultaneousness to communication that Habermas develops his variant of the concept of lifeworld. The lifeworld is defined as the context, composed of culturally and linguistically organised patterns of interpretation, within which the "sprach- und handlungsfähige Subjekte“31 find themselves. It is a common ground, comprising „Selbstverständlichkeiten oder unerschütterten Überzeugungen ", 32 which make it possible for two or more subjects to constitute a

26 Niklas Luhmann, „Die Gesellschaft der Gesellschaft", p. 527.

27 Jürgen Habermas, Theorie des kommunikativen Handelns, Band 1. Handlungsrationalität und gesellschaftliche Rationalisierung (Frankfurt am Main, Suhrkamp Verlag, 1981) p. 386.

28 Jürgen Habermas, Warheit und Rechtfertigung. Philosophische Aufsätze (Frankfurt am Main, Suhrkamp Verlag, 1999), p. 9. Italics in original.

29 Jürgen Habermas, "Wahrheit und Rechtfertigung", p. 9. Habermas' italics.

30 Ibid. p. 9. Habermas' italics.

31 Jürgen Habermas, "Theorie des kommunikativen Handelns, Band 1", p. 386.

32 Jürgen Habermas, Theorie des kommunikativen Handelns, Band 2. Zur Kritik der funktionalistischen Vernunft (Frankfurt am Main, Suhrkamp Verlag, 1981), p.189. 
common understanding of the world on the basis of an already existing shared interpretation of it.

Nevertheless, the lifeworld cannot just be a ground (Boden), but must also be a horizon, since the lifeworld is moving ahead at the same pace as the observer. Consequently, the lifeworld must be understood as constituted by the distinction between ground and horizon. According to Luhmann, this concept of lifeworld, developed by Hus$\operatorname{serl}^{33}$ and adopted by Habermas, ${ }^{34}$ is based on a paradox. This is because the lifeworld cannot be the firm ground where all observations and actions are unfolded and, at the same time, an infinite horizon which simply is the WORLD: it cannot be moveable, if it is firm and, if it is firm, it cannot be moveable. ${ }^{35}$ Consequently, Luhmann presents an alternative formulation of the problem, replacing the metaphorical concepts of horizon and ground with a distinction between familiarity and non-familiarity (Vertrautem/Unvertrautem). Now, familiarity represents the ground, and nonfamiliarity the horizon, thereby avoiding the contradictions inherent in the misleading opposition between the stationary and the movable as found in Husserl's and Habermas' concepts of lifeworld.

\section{Reiteration}

The central element in the calculus of indication, as already mentioned, is that only one side of a distinction, and not the other, is indicated at any given moment. Yet it always remains possible to perform a time-consuming crossing, from one to the other. Such a crossing, whose purpose is to indicate the other side, can in principle be reiterated infinitely. In principle, in this situation, on every occasion one's indication will be the same. However, though one always indicates the same, the result is never the same! ${ }^{36}$ This is because indication leads to condensation of the indicated. Every time an indication is reiterated, the observer obtains

33 Edmund Husserl, Erfahrung und Urteil (Claassen \& Goverts, Hamburg, 1948), § 7-9.

34 Jürgen Habermas, „Theorie des kommunikativen Handelns, Band 2“, p. $182 \mathrm{ff}$.

35 Niklas Luhmann, „Die Lebenswelt“, p. 177ff.

36 This insight originated with Kierkegaard's treaty Gjentagelsen. See Gjentagelsen: Et Forsøg i den experimenterende Psychologi af Constantin Constantius in Søren Kierkegaard. Samlede Værker, Bind 5 (København, Gyldendal, 1843 1995), pp. 113-194, English transl. Repetition: A Venture in Experimenting Psychology by Constantin Constantius in Howard and Edna Hoy (Editors), Fear and Trembling/ Repetition: Kierkegaard's Writings, Vol. 6 (N.J, Princeton University Press, 1983), which has also been a source of inspiration for different forms of post-modern thinking. For a literary example, see Milan Kundera, Nesnesitelná lehkost byti, 1984, English Transl. by Michael Henry Heim, The unbearable lightness of being (Faber, 1999), where the central distinction is weight/lightness, and where weight is constituted through reiteration. an increased feeling of what is being indicated. Reiteration attributes an additional value to the indicated, and it is exactly this value which Luhmann defines as familiarity. The lifeworld must therefore be understood as, "ein unvermeidliches Kondensat des Unterscheidens", 37 "because all indications have a side-effect, namely a higher degree of condensation. Consequently, Luhmann can elevate the lifeworld, so that it assumes the status of a central and omnipresent phenomenon: „Die Lebensweltdifferenz von vertraut/unvertraut ist und bleibt die älteste, urtümlichste primordiale Differenz, weil sie an jeder eingeführten Unterscheidung kondensiert. “38

This attribution has radical consequences. According to Luhmann, when one reiterates an operation, once the distinction familiar/unfamiliar has already been established through an earlier operation, then the crossing of a distinction, to indicate the other side, does not cancel indication of the side which one is leaving. ${ }^{39}$ Put differently, when an operation is a reiterated operation, both sides can, in fact, be indicated in the same moment. By the lights of Luhmann's own theory, therefore, reiteration must lead to dissolution of the given distinction, since both sides cannot be indicated at the same time if the distinction is to be maintained. Consequently, one can - at any time - embark on a journey into the unknown without giving up the known. Just as one can bring the unknown home, in the form of symbols, „we can live within a familiar world because we can, using symbols, reintroduce the unfamiliar into the familiar. We never have to leave the familiar world. It remains our life-world: We never cross the boundary: it remains a horizon that moves as we move. But we know in a familiar way about the unfamiliar". ${ }^{\prime \prime}$

With this approach, Luhmann presents a logically coherent and operative version of the phenomenological concept of lifeworld. ${ }^{41}$ Since he also clarifies when operative simultaneousness is possible, that is, when an operation is a reiterated operation, Luhmann also provides an answer to a crucial question, following automatically from Habermas' claim concerning the possibility of operative simultaneousness, and which Habermas himself has never answered.

\section{Context dependency}

Still, it is important to understand that incorporation of Habermas' notion of lifeworld in the system theoretical universe is not a one-sided undertaking. The concept of life-

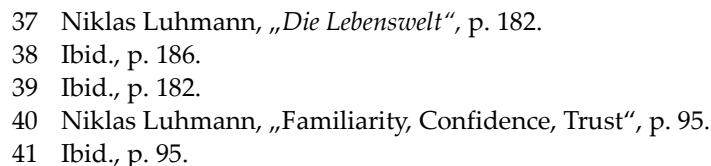


Poul Kjaer - Systems in Context

world, to a great extent, is a Trojan horse which, once inside the walls, can trigger a profound shift of focus within system theory itself. This is not just because the system theoretical concept of lifeworld can be used to clarify the conditions for achievement of operative simultaneousness; the concept of lifeworld can also rectify a basic flaw in systems theory. Systems theory does not contain a mechanism for determining what a system constitutes itself against, ${ }^{42}$ giving rise to systematic vagueness. Luhmann acknowledges that the surroundings of a system rarely remains undetermined: „Normally our indications will frame our observations with the effect that the other side implicitly will receive a corresponding specification" ${ }^{43}$ But this only serves to displace the problem, given its implication of the existence of a second, common boundary: „In this case the indication implies a double boundary, the inner boundary of the frame ... and the boundary of this frame“. 44

Moreover, Luhmann does not seem to take the consequence of the insight that the outside typically will be determined, since his empirical analysis' tends to give the impression that social systems can be viewed as detached phenomena's, which are being constituted through a distinction made in free air. Consequently, the strength of his empirical analyses is being massively reduced, in so far as they tend to render a somewhat implausible and counterintuitive impression of how society operates. This impression could, however, have been avoided if Luhmann had made the choice to systematically incorporate the system theoretical concept of lifeworld when conducting his empirical investigations.

\section{German Idealism}

System theory's lack of focus on the function of context is not an isolated technical problem. On the contrary, it is a fundamental defect that can be traced to Luhmann's attempt to de-couple systems theory from the German idealist tradition.

The importance of the problem of context within German idealism is demonstrated by the example of the colour red in Kants' Kritik der reinen Vernuft (1781): „Wenn ich mir rot überhaupt denke, so stelle ich mir dadurch eine Beschaffenheit vor, die (als Merkmal) irgend woran angetroffen, oder mit anderen Vorstellungen verbunden sein kann; also nur vermöge einer vorausgedachten möglichen synthetischen Einheit kann ich mir die analytische vorstel-

42 Jean Clam also draws the attention to this problem. See Jean Clam, "System's Sole Constituent".

43 Niklas Luhmann, "The Paradoxy of Observing Systems", p. 44.

44 Ibid., p. 44. len“. ${ }^{45}$ According to Kant, it is only possible to think the colour red through a simultaneous indication of the phenomena in relation to which the colour red stands. A thinking of the colour red, therefore, includes a thinking of the frame within which the colour red is constituted. ${ }^{46}$

This insight is a shaft that runs through Kant's work. In Kritik der Urteilskraft (1790), he concludes that judgments must have general validity, since an observer's judgment must be related to those of other observers concerning the same issue. In turn, this implies the existence of a frame of possible, comprehensible and perhaps overlapping, though not necessarily completely identical, judgments: „,... da der Urteilende sich in Ansehung des Wohlgefallens, welches er dem Gegenstande widmet, völlig frei fühlt: so kann er keine Privatbedingungen als Gründe des Wohlgefallens auffinden, an die sich sein Subjekt allein hinge, und muß es daher als in demjenigen begründet ansehen, was er auch bei jedem andern voraussetzen kann; folglich muß er Glauben Grund zu haben, jedermann ein ähnliches Wohlgefallen zuzumuten“. ${ }^{47}$ So, whereas Luhmann erases the concept of context from the calculus of indication (in notable contrast to Spencer-Brown), thereafter stating that distinctions are typically made within a context and producing a vast number of empirical analyses where the importance of context is downplayed as much as possible, Kant's work is characterised by greater coherence between the logical foundations and concrete analysis of social phenomena.

Hegel, likewise taking a distinction introduced in a given context as his starting point, presents a perspective similar to Kant's. In the debate between Luhmann and Gerhard Wagner and others, unfolding on the pages of Zeitschrift für Soziologie between 1991 and $1995^{48}$ and which focused on the relationship between systems theory and Hegelian logic, Wagner argued that Luhmann's adaptation of the calculus of indication modifies the calculus in a way which makes his position identical to Hegel's. Wagner suggested that, whereas Spencer Brown's logic of distinction assumes that the sides of a distinction must be considered as symmetric and side-neutral, ${ }^{49}$ the most important change introduced by Luhmann lies in the latter's contrary claim that,

45 Immanuel Kant, Kritik der reinen Vernuft. Werkausgabe Band III und IV (Suhrkamp Verlag. Frankfurt am Main, [1781], 1974), B134

46 Will Martens is also using the example of the colour red in his comment to the relationship between identity and difference within systems theory. But his point of departure is Hegel instead of Kant. See Will Martens, Der verhängnisvolle Unterschied. Bemerkungen zu den Beiträgen von Gerhard Wagner und Niklas Luhmann in der ZfS 4 und 6 1994, (Zeitschrift für Soziologie, Jg. 24, Heft 6, 1995, pp. 229-234).

47 Immanuel Kant, Kritik der Urteilskraft. Werkausgabe Band X (Suhrkamp Verlag. Frankfurt am Main, [1790], 1974), B27, B18. 
„Observations are asymmetric (or symmetry-breaking) operations ". ${ }^{50}$ As is well known, such asymmetric relations include the distinctions master/slave, subject/object, system/surroundings and text/context, ${ }^{51}$ where the emphasis is placed on the former in each pair. According to Luhmann, asymmetries are necessary, as already mentioned, because "the inner side has connective value ${ }^{\text {" }}{ }^{52}$ A system can only reproduce itself by attaching itself recursively to the inner side: „The inner side is where the problem is - the problem of finding a suitable next operation". ${ }^{53}$ In other words, the key issue is to connect a purely formal logic with a social theoretical operationalisation of this logic, and this necessitates the introduction of the concept of asymmetrical distinctions. ${ }^{54}$

In Wagner's view, this change is crucial since it implies a shift in focus from dissimilarity (,Verschiedenheit") to contradictions („Gegensatzpaare“). Dissimilarity, according to Hegel, is simple difference, in the sense that there is nothing in the two units necessitating their dissimilarity. It is purely external, lacks any logical foundation, and is based exclusively on observation. Amongst typical dissimilarities are those observed in comparing a car with an orange, or an elephant with a pen. Oppositely, for Hegel, contradiction is

48 See Niklas Luhmann, Am Ende der kritischen Soziologie (Zeitschrift für Soziologie, Jg. 20, Heft 2, April, 1991, pp. 147-152), Gerhard Wagner and Heinz Zipprian, Identität oder Differenz? Bemerkungen zu einer Aporie in Niklas Luhmann's Theorie selbstreferentieller Systeme (Zeitschrift für Soziologie. Jg. 21, nr. 6, 1992, pp. 394-405), Niklas Luhmann, Bemerkungen zu "Selbstreferenz" und zu "Differenzierung" aus Anlaß von Beiträgen im Heft 6, 1992, der Zeitschrift für Soziologie (Zeitschrift für Soziologie, Jg. 22, Heft 2, April, 1993, pp. 141-146), Gerhard Wagner and Heinz Zipprian, Anwort auf Niklas Luhmann (Zeitschrift für Soziologie. Jg. 22, 1993, pp.144-46), Armin Nassehi, "Das Identische, ist' das Nicht-identische", Gerhard Wagner, Am Ende der systemtheoretischen Soziologie. Niklas Luhmann und die Dialektik (Zeitschrift für Soziologie, Jg. 23, nr. 4, 1994, pp. 275-291), Niklas Luhmann, Gesellschaft als Differenz: $Z u$ den Beiträgen von Gerhard Wagner und Alfred Bohnen in der Zeitschrift für Soziologie Heft 4 (1994) (Zeitschrift für Soziologie. Jg. 23, Heft 6, Dezember, 1994, pp. 477-81), Will Martens, „Der verhängnisvolle Unterschied“.

49 Gerhard Wagner, "Am Ende der systemtheoretischen Soziologie“, p. 279.

50 Niklas Luhmann, Deconstruction as Second-Order Observing (New Literary History, 24, 1993, pp. 763-782), p. 769. More forcefully: „Deutlicher als dies bei Spencer Brown geschieht, sollte hier festgehalten werden, daß Unterscheidungen...in einer fundamentalen Weise asymmetrisch sind“. See Niklas Luhmann, "Die Lebenswelt", p. 181. Also quoted in Gerhard Wagner, "Am Ende der systemtheoretischen Soziologie“, p. 278.

51 Niklas Luhmann, "Gesellschaft als Differenz", p. 280.

52 Niklas Luhmann, "Deconstruction as Second-Order Observing“, p. 769.

53 Ibid., p. 769.

54 Niklas Luhmann, Neuere Entwicklungen in der Systemtheorie (Merkur. Deutsche Zeitschrift für europäisches Denken, vol. 42, 1988, pp. 292-300), p.296. dissimilarity refined in a particular way: a contradiction is based on an inner difference, where the two sides depend on each other. This is true, for instance, of concepts such as positive/negative (Hegel's own example), man/woman and system/surroundings (Wagner's examples), and the concepts of immanent/transcendent, being/non-being or property/non-property (Luhmann suggestions).$^{55}$ According to Hegel, the logical unity of such contradictions is expressing identity, since the distinctions are dependent on each other, which makes them "in einer Identität verschiedene ${ }^{\text {“ }}{ } 6$ Hence, Wagner argues that Luhmann does not succeed in forcing a social theoretical paradigm shift by changing the focus from identity to a focus on difference, as was his intention, since his distinctions are, like Hegel's, determined distinctions. $^{57}$

\section{Paradox}

Luhmann recognises that ,all observations have to presuppose the existence of both sides of a distinction or ,frame' " ${ }^{58}$ Nonetheless, the consequence of his views as described above is to refute that systems theory is based on a concept of identity. Instead, he argues, his theory is founded on the paradox which results from his concept of observation. ${ }^{59}$ An observation, as stated above, is an operation that indicates one side of a distinction, but not the other. A distinction of two sides, however, implies the existence of a blind spot, since the observer can observe, but cannot observe his own observation. Only a new, time-generating, observation can do that. One can, therefore, distinguish between a first order observer who focuses on what (was) is observed, and a second order observer who observes how (wie) the first order observer observes. The second order observer can see what the first order observer cannot - the first order observer's observation. Yet this does not give the second order observer a privileged position, since she cannot observe her own observation either. The second order observer is therefore a first order observer herself when she is being observed by another third order observer.

55 Niklas Luhmann, "Deconstruction as Second-Order Observing", p. 769.

56 G. W. F. Hegel, Wissenschaft der Logik II. Werke in zwanzig Bänden, Bd. 6 (Suhrkamp Verlag. Frankfurt am Main, [1813] 1970), p. 60.

57 Illustration of the context-problem in German idealism could, and should, be extended in order to include the positions of Fichte and Husserl, but that task is beyond the scope of this article.

58 Niklas Luhmann, "Deconstruction as Second-Order Observing", p. 769. Luhmann adopts the term "frame" from Erving Goffman, and claims that his use of it accords with Goffmann's intentions. See footnote 21 in Niklas Luhmann, "Deconstruction as Second-Order Observing".

59 Niklas Luhmann, "Gesellschaft als Differenz", p. 477ff. 
Poul Kjaer - Systems in Context

The concept of observation allows Luhmann to avoid Wagner's critique: Luhmann can claim that the only basic element in systems theory is observations observing other observations. Observations consist of the unity of a distinction and an indication, which means they are a unity of two different elements. Since Luhmann defines a paradox as the unity of different things, he is entitled to conclude that the true basis of systems theory is paradox, not identity. ${ }^{60}$

Hence, in denying the concept of identity as the basic concept of systems theory, the Luhmann of the late 1980s and 1990s abandoned not only identity, but also the concept of distinction as well. The late Luhmann, in other words, exceeded the distinction between distinction and identity, in order to base his theory on paradox.

\section{Meaning}

According to Husserl, Habermas as well as Luhmann himself the function of the concept of lifeworld is to evade the kind of paradoxes on which the late Luhmann focused.

Nevertheless, Luhmann claims that a concept of world is too general to serve as a basis for any profound analysis of social phenomena. ${ }^{61}$ An alternative framework for achieving de-paradoxialisation, he suggests, would arise from an answer to the question: „How is it possible to observe frames?“62 And to develop such a framework, Luhmann instead emphasises the concept of meaning (Sinn): "we will certainly need a medium that is the same on both sides of the frame, on its inside and on its outside. I propose to call this medium meaning" ${ }^{63}$ The latter concept, according to Luhmann, is "coextensive with the world" ${ }^{64}$ So, while he believes the notion of world to be excessively general, he apparently considers the concept of meaning more useful - in spite of the fact that it includes phenomena identical in extent to the world. Luhmann's rationale for avoiding the notion of world must therefore lie elsewhere. One part of it is that, „,Sinn ist...ein Produkt der Operationen, die Sinn benutzen, und nicht etwa eine Weltqualität, die sich einer Schöpfung, einer Stiftung, einem Ursprung verdankt ${ }^{\prime 65}$ The main purpose of distinguishing the concepts of world and meaning, in other words, is to avoid associations with the Story of the Creation and other acts of initia-

60 Niklas Luhmann, "The Paradoxy of Observing Systems“, Niklas Luhmann, "Die Gesellschaft der Gesellschaft", p. 57 f., Niklas Luhmann, "Die Paradoxie der Form".

61 Niklas Luhmann, "The Paradoxy of Observing Systems", p. 41.

62 Ibid., p. 41.

63 Ibid., p. 41. Luhmann's italics.

64 Ibid., p. 41.

65 Niklas Luhmann, "Die Gesellschaft der Gesellschaft", p. 44. Luhmann's italics. tion. Thus, the distinction between world and meaning does not seem particularly salient, when it is seen in relationship to the concepts of lifeworld developed by Husserl, Habermas and Luhmann himself, since they all understand the lifeworld as a product of continued social operations, and not as the result of an act of initiation. Consequently, it is difficult to identify the real difference between, on one hand, the intended function of Luhmann's concept of meaning and, on the other, the notion of lifeworld, as it occurs in the works of Husserl and Habermas: both concepts aim at the observation of "frames" - in other words, contexts which can be defined as operationally constituted unities, comprising a distinction and both of its sides.

More concretely, the function of the concept of meaning in Luhmann is to achieve de-paradoxialisation through a neutralisation of the asymmetry he was earlier forced to introduce into the calculus of indication, in order to make it an operational social theoretical tool: „Sinn ist also eine Form, die auf beiden Seiten eine Copie ihrer selbst in sich selbst enthält. Das führt zur Symmetrisierung des zunächst asymmetrisch gegebenen Unterschiedes". ${ }^{66}$ As an upshot, Luhmann could have circumvented Wagner's critique, and at the same time avoided entering the labyrinth of paradoxes if he had complemented the move towards a focus on paradoxes with an upgraded concept of meaning. The concept of meaning, as already suggested, can be used to describe the kind of social continuity required to ensure a balancing of the fundamental experience of social discontinuity which follows from the introduction of a distinction. On this background, an upgraded concept of meaning could have emphasised that the constant flow of social operations is conditioned just as much by the continuing reproduction of a medium which is identical on both sides of any given distinction as it is characterised by a reproduction of paradoxical tensions. Luhmann chose not to go down this path and his contingent choice to pursue an essentially paradox-based theory instead threatens to undermine one of the key elements of systems theory, namely its ability to explain how social structures can be characterised by rupture and stability at the same time. In tandem, a radical focus on paradoxes threatens to transform Luhmann's theoretical construction into a purely metaphorical exercise.

The concept of meaning, therefore, remains irreplaceable but also crucial to the theory's overall viability. While this, in principle, was recognised by the late Luhmann, ${ }^{67}$ he never transformed the concept of meaning into

66 Ibid., p. 50

67 Niklas Luhmann, „The Paradoxy of Observing Systems“, p. 41. 
a useable tool for describing social phenomena. Instead, it was retained as a general background notion, encompassing everything and therefore signifying nothing. As a consequence, Luhmann's concept of meaning is not sufficiently precise to rectify the systematic vagueness of systems theory, identified above, which prevents determination of what it is a given system constitutes itself against.

The failing concretisation of the concept of meaning could have been offset by the concept of trust. Yet, while the early Luhmann built up an elaborate concept, ${ }^{68}$ trust was subsequently marginalised, and almost never deployed by Luhmann to describe the interaction of social structures.

Moreover, the emphasis of paradox is not in itself sufficient to constitute a break between systems theory and German idealism. Both Kant and Hegel acknowledge the paradoxical character of the world. Kant expresses this through the distinction between nature and freedom, which also constitutes the world as a unity of difference. Hegel's starting point is the paradoxical unity of the identical and nonidentical. Thus, neither Kant nor Hegel dismisses the fundamental significance of paradox. Instead they supplement this ancient insight, introducing the concepts of judgment and spirit. These they use to establish distance from a given distinction, without dissolving it, with the aims of balancing the experience of paradox, and enhancing the possibility of observing contexts within which distinctions are drawn. Judgment and spirit, in other words, are to the Kantian and Hegelian theoretical edifices, as the concept of meaning is to systems theory. As illustrated above, though, Luhmann's idealist predecessors achieved greater coherence than did he, between the logical foundations of their respective theories and the level of elaboration necessary to generate concrete analyses of social phenomena.

\section{Self-mystification}

System theory's inability to grasp the significance of the context of distinctions is also applicable to the theory itself. In responding to this flaw Luhmann developed a sophisticated self-mystification strategy, ${ }^{69}$ devising a highly imaginative terminology to go with it. Indeed, so successful was he in this strategy, that many present day system theoreti-

68 Niklas Luhmann, „Vertrauen: ein Mechanismus der Reduktion sozialer Komplexität", 4. Auflage, Stuttgart: Lucius und Lucius, 2002.

69 The direct result of this self-mystification strategy was the creation of an autonomous universe through the development of hundreds of new concepts. Consequently, it has been deemed necessary to publish a dictionary aimed at explaining this new language to the rest of the world. See Detlef Krause, Luhmann-Lexikon: eine Einführung in das Gesamtwerk von Niklas Luhmann (Lucius \& Lucius, Stuttgart, 2001). cians appear to believe that Luhmann himself was responsible for the basic concepts of the systems theory. Consequently, many theoreticians also believe that systems theory is not embedded in any existing tradition - a problematic view, given that most system theoretical concepts derive almost directly from German idealism. For example, this is true of the basic distinction system/world, resembling the traditional subject/object distinction; the concepts of meaning (Husserl), autopoesis and temporalisation (Kant, Fichte and Husserl); Luhmann's version of the calculus of indication (Kant, Hegel); and the concepts of causality, reflexivity and rationality (Kant) and self-reference (Kant, Fichte). So, even though Luhmann „never engages in a painstaking and subtle reading of the classical canon of social theory", 70 of the type undertaken by Derrida and Habermas, amongst others, one must agree with Habermas' statement that Luhmann's „Unternehmung sucht Anschluß ... an die Problemgeschichte der bewußtseinsphilosophie von Kant bis Husserl. ${ }^{\prime 71}$

Failure to acknowledge this heritage is becoming a major threat to the systems theory's future utility as a tool for social theoretical analysis. This is because, firstly, it has the consequence that many of Luhmann's disciples are only capable of defending systems theory from within, whereas they require a language bestowing a capacity to argue outside its own frame ${ }^{72}$; secondly, because it provides a structural basis for theoretical fundamentalism, visible, for example, in the attempt to elevate the calculus of indication to a position where it supplies the basis of all other system theoretical concepts. Electing such a strategy for further theoretical development, however, undermines one of the strongest elements of system theory - namely, the stability its non-reductionist version possesses as a system, precisely because it is not based on any one element but on a whole range. One can always fetch another tool from the box if the first does not seem to fit. Such plurality also secures the theory against the kind of foundationalism which, as a radical anti-totalitarian, Luhmann sought to avoid.

Were a fundamentalist and purely paradox-oriented version of systems theory to achieve discursive dominance, the reduction of the theoretical complex to a Zeitgeist phe-

70 Urs Stäheli, Writing Action: Double Contingency and Normalization (Distinktion. Tidsskrift for samfundsteori, Nr. 1, 2000, pp. 39-47), p. 40.

71 Jürgen Habermas, Der philosophische Diskurs der Moderne. Zwölf Vorlesungen (Suhrkamp Verlag, Frankfurt am Main, 1989), p. 426.

72 Stefan Rossbach The myth of the system: On the development, purpose and context of Niklas Luhmann's systems theory, pp. 1-36, http:// www.essex.ac.uk/ecpr/events/jointsessions/paperarchive/copenhagen/ws9/rossbach.PDF, p. 36. 
Poul Kjaer - Systems in Context

nomenon would also be likely. Especially so, given that a historical view of the up- and downturns of thinking in paradoxes reveals that a focus on paradoxes, with irony as its faithful guardian, expands in periods of transition. ${ }^{73}$ Thus, it is no coincidence that the paradox-oriented version of systems theory had its breakthrough in terms of social science in the 1990s, an époque dominated by discontinuity arising from political upheaval, the dissolution of systems of thought, and the expansion of fin de siècle semantics.

On an alternative view systems theory represents a further development of the German idealist tradition of Kant, Fichte and Hegel to Husserl, which presents solutions to a number of crucial but as yet unresolved problems within that tradition. In contrast to earlier forms, systems theory is an explicitly post-ontological theory. Moreover, Luhmann delivers the first convincing description of the relationship between the self- and external reference of social systems, so solving the problem of solipsism, an important dilemma in German idealism since Fichte's problematisation of the tautological constitution of the subject in the works of the early Kant. ${ }^{74}$ That Luhmann was able to offer solutions to such problems provides a good illustration of systems the-

73 The classic example here is the Renaissance, where thinking in paradoxes, especially within the literature of scepticism, became a widespread form of argumentation. See Barbara C. Bowen, The Age of Bluff. Paradox $\mathcal{E}$ ambiguity in Rabelais $\mathcal{E}$ Montaigne (Chicago. University of Illinois Press, 1972), Rosalie L. Colie, Paradoxia Epidemica: The Renaissance Tradition of Paradox (Princeton, N.J., 1966), A. E. Malloch, The Techniques and Function of the Renaissance Paradox (Studies in philology, vol. 53, 1956, pp. 191-203) and Michael McCanles, Paradox in Donne (Studies in the renaissance, vol. 13, 1966 pp. 266-287). During the Renaissance, however, there was also widespread understanding of the limitations of paradox, since it is a self-destructive form of argument, where an argument only can be met through dissolution of the argument which one chooses to refute it with. Or, as expressed by Montaigne, quoted after A. E. Malloch, "The Techniques and Function of the Renaissance Paradox", p. 203: „... this final fencer's trick [the paradox] should not be employed except as a last resource. It is a desperate thrust, in which you have to abandon your weapon in order to disarm your adversary, and a secret ruse which should be practised seldom and with reserve. It is a very foolhardy thing to lose your life in order to kill another". The paradox, in other words, serves as a doctrine for mutually assured destruction of argumentation, in the sense that it serves at the constitutive fundament for any argument at the same time at it remains impossible to use in practice. Luhmann's dismissal of the distinction between distinction and identity in order to reject the concept of identity illustrates this point very well.

74 Niklas Luhmann, Die Form „Person", pp. 142-54 in: Niklas Luhmann, Soziologische Aufklärung 6. Die Soziologie und der Mensch (Opladen, Westdeutscher Verlag, 1995, Original printed in Soziale Welt, 42, 1991, pp. 166-75), p. 143ff. See also Dieter Henrich, Fichtes ursprungliche Einsicht (Vittorio Klostermann, Frankfurt am Main, 1967). ory's influence extending far into the universe of philosophy, notwithstanding Luhmann's flirtatious rejections. ${ }^{75}$

Inveterate system theoreticians might reject a „return to Kant and Hegel“ as a waste of time, or as absurd. But the suggestion is not for a revival of thinking of the kind which dominated the era of the French Revolution. Instead, questions such as "Hegel or Luhmann?" a focus of the Luhmann/Wagner-debate, should be rejected since it is not a case of either or. Rather, it is necessary systematically to confront systems theory with its own basis. This genealogical endeavour would allow the theory's liberation from its own self-mystifying semantics without total rejection. Then, Luhmann's rich social theoretical toolbox can be reopened and its contents applied to promote perspectives on society other than the variety of societal scepticism advocated by the late Luhmann - a choice that anyhow seems to reflect the specificities of Luhmann's personality, and his experiences as a youth in Nazi Germany, rather than any theoretical necessity. ${ }^{76}$

\section{Convergence}

If systems theory is "opened up", as described above, it becomes more compatible with other theories, and especially with the theoretical complex resulting from Habermas' reconstruction and renewal of German idealist insights. Compatibility, though, is only a structural condition, providing a possibility, but not a guarantee, of convergence. In Faktizität und Geltung (1992) Habermas condensed the debate between himself and Luhmann, recycling more general social theoretical questions into the language of legal theory. Habermas' legal theory, moreover, dramatically increased the links between his general theory and the system theoretical complex. So far reaching were these changes that it is possible to view Habermas' theory after Faktizität und Geltung as a normative superstructure to Luhmann's descriptive theory of society.

Of these substantial changes, the first was the introduction of the concept called "höherstufige Intersubjektivität ${ }^{\prime 77}$ also characterised as a kind of ",subjektlose Kommunikation“. ${ }^{78}$ With this move, Habermas takes an important

75 Niklas Luhmann, Paradigm Lost: Über die ethische Reflexion der Moral. Rede anläßlich der Verleihung des Hegel-Preises (Frankfurt am Main, Suhrkamp Verlag, 1989), p. 9. This was also recognised by Habermas through his characterisation of Luhmann as "der wahre Philosoph". See Jürgen Habermas, Die Einbeziehung des Anderen. Studien zur politischen Theorie (Frankfurt am Main, Suhrkamp Verlag, 1997), p. 393.

76 Stefan Rossbach, "The myth of the system".

77 Jürgen Habermas, Faktizität und Geltung. Beiträge zur Diskurstheorie des Rechts und des demokratischen Rechtsstaats, (Frankfurt am Main, Suhrkamp Verlag, 1992), p. 362. 
step towards abandoning the subject as the nucleus of his theory, ${ }^{79}$ thereby mitigating one key difference between the design of his own and of systems theory. Unfortunately, though, Habermas has never clarified with what alternative he intends to replace the concept of the subject. Consequently, it remains difficult to see how his theory can become viable without adoption of an elaborated concept of social systems.

The second substantial change concerns the relationship between law and morality. When Habermas developed his discourse ethics together with Karl Otto Apel in the 1980s, he insisted on the priority of morality over law. ${ }^{80}$ Yet in Faktizität und Geltung he states „ich gehe davon aus, da $\beta$ sich auf dem nachmetaphysischen Begründungsniveau rechtliche und moralische Regeln gleichzeitig aus traditionaler Sittlichkeit ausdifferenzieren und als zwei verschiedene, aber einander ergänzende Sorten von Handlungsnormen nebeneinander treten $"{ }^{81}$ Hence, Habermas no longer presumes the existence of a hierarchical relationship between morality and law, and abandons the attempt to uphold the kind of transcendentalism on which he previously insisted. ${ }^{82}$ At the same time, this alteration raises the question of how society is being integrated. Declining to provide any straight answer, by implication Habermas accepts another key insight from Luhmann's theory of the society: one must assume, when not integrated through morality, ,[dass] die codes der Funktionssysteme auf einer Ebene höherer Amoralität fixiert werden müssen“. 83

Concretely, this means that it is impossible to insist on the idea of discourse ethics as a viable framework for a theory of legitimate coordination within the realms of law and politics. The alternative is a discourse theory aimed at developing tools for achieving coordination, which do not

78 Jürgen Habermas, „Faktizität und Geltung“, p. 362.

79 As Luhmann points out, it is important to remember that a theory of intersubjectivity has the subject, and not an unspecified "inter", as its key element. See Niklas Luhmann, Intersubjektivität oder Kommunikation: Unterschiedliche Ausgangspunkte soziologischer Theoriebildung, pp. 169-88 in Niklas Luhmann, Soziologische Aufklärung 6 Die Soziologie und der Mensch (Opladen, Westdeutscher Verlag, 1995. Original printed in Archivio di Filosofia, 54, 1986, pp. 41-60), pp. $169 \mathrm{ff}$.

80 See Jürgen Habermas, Diskursethik - Notizen zu einem Begründungsprogramm, pp. 53-126 in: Jürgen Habermas, Moralbewusstsein und kommunikatives Handeln (Frankfurt am Main, Suhrkamp Verlag, 1983) and Jürgen Habermas, Erläuterungen zur Diskursethik (Frankfurt am Main, Suhrkamp Verlag, 1991).

81 Jürgen Habermas, „Faktizität und Geltung“, p. 135. Habermas' italics.

82 This move was criticized strongly by Karl Otto Apel. See K.O. Apel, Auseinandersetzungen in Erprobung des Transzendentalpragmatischen Ansatzes (Frankfurt am Main, Suhrkamp Verlag, 1998).

83 Niklas Luhmann, "Die Gesellschaft der Gesellschaft", p. 751. claim that such coordination necessarily must be derived from morality. This is also explicitly recognised by Luhmann: „Der diskurstheoretische (im Unterschied zu einem diskursethischen) Legitimationsbegriff, den Jürgen Habermas vorgesellt hat, paßt genau in diese Theorieposition [The system theoretical position]. Er besteht aus den beiden Teilen, die man für eine Kontingenzformel benötigt: einem gänzlich unbestimmt bleibenden Teil, der in der Aussicht auf Lösung von Kontroversen durch vernünftigen Konsens (Einverständnis oder Vereinbarung) aller Betroffenen besteht, und der Überführung dieses Letztsinns in handhabbare Verfahrensregeln, die die Vermutung rechtfertigen, da $\beta$ ein solcher Konsens eventuell erzielt werden könnte. “84 The move away from a discourse ethics, and to a discourse theory, in other words, points towards replacement of the "old-European" striving for totality on the basis of a concept of morality, with a functional and pragmatic approach, seeking to develop and deploy tools that can ensure a continued coordination of the ongoing reproduction of autonomous social systems. Consequently, the design of mechanisms enabling such coordination is reduced to the legal task of developing relevant procedural rules and safeguards. The criteria for success, moreover, are being reduced to empirical questions about the degree of coordination achieved. In parallel, the normative element is restricted to evaluation of the success of different coordinating measures, and their respective abilities to achieve coordination without damaging the continued reproduction and expansion of the functional differentiation of society.

Such an undertaking can be supported by insights contained in the system theoretical concepts of morality and critique. As has several times been mentioned, the starting point for the late Luhmann is the introduction of a distinction, characterised by the existence of an asymmetrical relationship between its two sides. In that context, the function of meaning is to re-introduce symmetry into the relation between the two sides, so creating a two-dimensional form which, at the same time, is characterised by symmetry and asymmetry. It is against this background that Luhmann introduces his concept of morality, stating that „Moral ist immer symmetrisierter Sinn". ${ }^{85}$ The consequence is that he can understand morality as exercising an alarm function within the modern society, in the sense that moral communication highlights pressing problems and asymmetries that threaten to undermine the reproduction of functional

84 Niklas Luhmann, Die Politik der Gesellschaft (Frankfurt am Main, Suhrkamp Verlag, 2000 - published posthumously), p. 124f.

85 Niklas Luhmann, "Die Gesellschaft der Gesellschaft", p. 242. 
differentiation. In contrast to a traditional understanding of morality, as some sort of super medium, this allows for an understanding of morality as a specific form of communication which exercises a "support function" for the procedural rules and safeguards deployed to ensure coordination under the condition of continued functional differentiation.

Luhmann's concept of morality makes it possible to question his claim that the system theoretical concepts of lifeworld and meaning do not provide a basis for critique of modern society. ${ }^{86}$ This is because the introduction of the binary code symmetry/asymmetry de facto defends a "balanced society", free from the excessive reduction of meaning which would flow from asymmetric relations between different social systems. ${ }^{87}$ Thus, Luhmann himself also provides concepts that can be applied to achieve objectives set by Habermas.

\section{Conclusion}

The almost complete incorporation of Habermas' theory into the systems theoretical complex prompts the question: how much of Habermas' attempt to develop an independent theoretical position actually persists? It appears that Luhmann left almost nothing behind. Still, Luhmann did not go far enough in attempting to incorporate Habermas' theory. He developed a concept of lifeworld, but instead of using it, he abandons it. Instead, he continues to rely on the identical concept of meaning. The latter however, is retained as a general background notion of little use in practice. The concept of trust developed by Luhmann, and which can in many respects be regarded as the practical concretisation of the concept of meaning (in the same way as Habermas' concept communicative action can be seen as a concretisation of his concept of lifeworld) is also left behind, and almost never applied in Luhmann's empirical analyses of society. Luhmann's concept of understanding suffers the same fate, and the same can be said of his treatment of the very Habermasian concepts of morality and critique. None of Luhmann's "translations" of Habermasian concepts, in other words, are effectively deployed. Yet, these concepts need to be applied, and need to achieve a fundamentally different status within systems theory, since they could solve a number of its central flaws - such as its inability to determine what it is a given system constitutes itself against, and the weakness of Luhmann attempt to couple formal logic with a concept of social operationalisability.

In sum, one outcome of the Habermas/Luhmann debate is that the late Habermas' discourse theory can be regarded as a normative superstructure to Luhmann's descriptive theory of society. But a second is that, beyond the tendency to the two theoretical complexes' convergence, a complete fusion, through the development of a fully fledged ,intersystemic" and "critical" systems theory, could provide a viable basis for further theoretical development. Such a theory might provide an optimal frame for the continuing reformulation of legal theory.

86 Niklas Luhmann, „Die Lebenswelt“, P. 188.

87 Typical examples of asymmetries which lead to moral substitution are when the economy enters the system of intimacy in the shape of prostitution, when the medical system colonises the system of sport through doping, or when the religious system enter the pedagogical system through an intrusion of evangelism in the class room. That these examples not only refer to the systems of economy and power, and their colonisation of their surroundings, as described by Habermas, illustrates the superiority of Luhmann's concept of balance, compared with Habermas' concept of colonisation. 